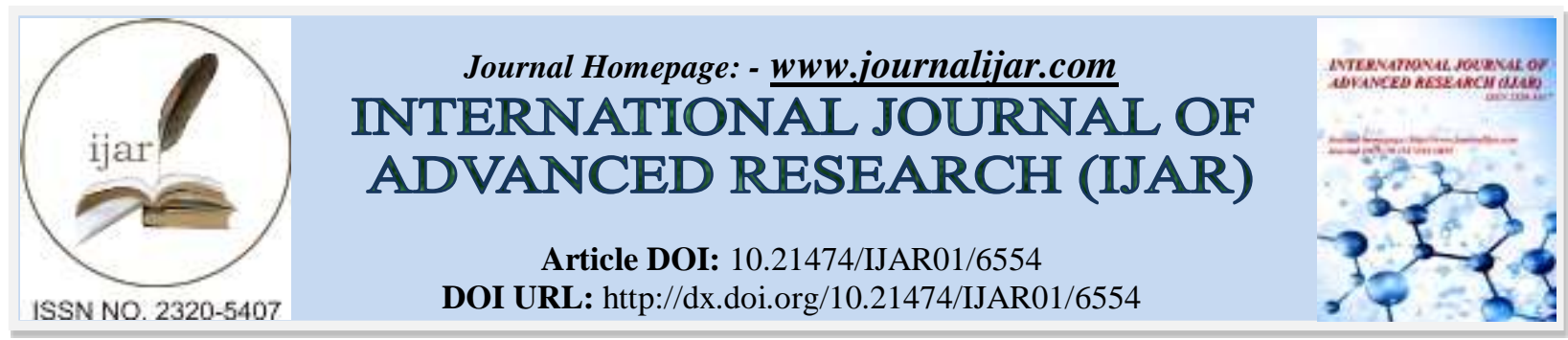

RESEARCH ARTICLE

\title{
APPRAISING THE DETERMINANTS OF CAPITAL MARKET DEVELOPMENT: THE RETROSPECT AND PROSPECTS FOR THE CEMAC ZONE.
}

Bande Gulbert Mbah Tarh.

Ph.D. in Law, Lecturer - University of Maroua.

\section{Manuscript Info}

Manuscript History

Received: 16 December 2017

Final Accepted: 18 January 2018

Published: February 2018

Key words:-

Determinant, Capital Market, Stock

Market, Development, CEMAC.

\begin{abstract}
An integral part of capital market is the stock market - the development of which is linked with the country's level of savings, investment and rate of economic growth. This article in all its potency, seeks to investigate the determinants of capital market development and its legal trends and challenges in the CEMAC zone. In this regard, it scrutinizes and provides further evidence on the relationship between capital market development and economic growth, using information from the CEMAC sub-region. Thus, from this, the findings obtain reveal that the initiatives of capital market development and capitalization can induce economic growth in the CEMAC countries. In this light, the perception and significance of the determinants of capital market development considered in this article, provides encouraging signals for the CEMAC countries to emulate and explore capital markets, as potential avenue for enhancing and expediting economic growth. More so, the incidence of corruption, rule of law and quality of regulatory framework are identified as the most important institutional frameworks that determine the attractiveness of African countries to the inflow of FDI. Therefore, the article suggests that there is need for the CEMAC countries to initiate viable and sustainable policies that are capable of improving the institutional environment, in order to enhance the effective and efficient development and performance of the capital markets, and ultimately, boost the attractiveness of the sub-region to the inflow of FDI and, thus, economic growth.
\end{abstract}

Copy Right, IJAR, 2018, All rights reserved.

\section{Introduction:-}

In point of fact, Levine and Zervos assert that 'the world stock markets are booming and stock markets in developing countries account for a disproportionately large share of this boom; enabling investors to venture into the world's newest markets and some seeing handsome returns; but the pertinent question they posed is, are the developing countries themselves reaping any benefits from their stock markets? ${ }^{11}$ In this respect, there exists an overwhelming consensus that well-functioning financial intermediaries have played a significant role in economic growth. ${ }^{2}$ But

${ }^{1}$ Levine, R. and Zervos, S. (1996)., Stock markets development and long-run growth. The World Bank Economic Review 10 (2), pp. 323-339.

2 King, R. and Levine, R. (1993a). "Financial Intermediation and Economic Development." in Financial Intermediation in the Construction of Europe. Editors: Colin Mayer and Xavier Vives. London: Centre for 
more recently, the emphasis has increasingly shifted to stock market indicators, and the effect of stock markets on economic development, with the latter being the subject of recent theoretical interest. ${ }^{3}$ Although some analysts view stock markets in developing countries as "casinos" that have little positive impact on economic growth, recent evidence suggests that stock markets may give a big boost to economic development. In fact, the focus on stock markets as an engine of economic growth is a new opening in financial literature. Going further, its benefits had been largely ignored in the past, but now there is consensus concerning the positive effects brought about by stock markets. ${ }^{4}$ In this regard, capital markets have been described as an exciting challenge for international finance and foreign investment. In Africa as reiterated above, they are looked upon as having both promise and peril, and with potentials for remarkably high returns, while simultaneously harboring substantial risks. Their emergence in the last two decades in most countries in Sub-Saharan Africa (SSA), have arguably been the most important aspect of foreign investment, finance, and economic development in contemporary Africa. ${ }^{5}$

Moreover, it has been argued that, global capital flows have the potential to positively affect the development processes by augmenting domestic savings and contributing to investment, growth, financial sector development, technological transfer and poverty reduction. In this regard, the impact of this source of investment finance in the economic is, therefore, that the countries or regions where the market(s) are based will benefit from long-term loans to help finance projects and enhance economies of scale. Equally, the market(s) can provide both an informational mechanism in evaluating the performance of domestic firms, and finally the growth of related financial service sectors, for instance, insurance pension and provident schemes, which nurture the spirit of savings, improvement of access to finance new and smaller companies. Thus, the performances of a stock market, that is, its ability to assert its influence on foreign investors and global financiers can only be done if the country is able to address its macroeconomic and political needs. ${ }^{6}$ Therefore, the reality of the global market is that the decisions of foreign investors rest on the following factors: political stability, economic stability, local market access, transparency, legal framework, and quality of life among others. In fact, some stock markets in SSA have been described as being emerging stock markets based on the criteria above. These markets have seen substantial improvement, in their macro-economic and political spheres, to have warranted investors to bring in much needed capital flow. ${ }^{7}$

In this regard, however, one of the reasons attributed to the reluctance of MNCs to invest in less developed countries, particularly in the Central Africa Economic and Monetary Community (CEMAC) zone, has been identified as risk aversion. ${ }^{8}$ In corroboration to this, the political economy of most African countries has still remained shaky, with most African capital markets generally regarded as fledgling and lacking the requisite

Economic Policy and Research, pp. 156-89; King, R. and Levine R. (1993b). Finance and Growth: Schumpeter Might Be Right. Quarterly Journal of Economics, 108(3), pp. 717-37; Levine R. and Zervos A. (1998). Stock Markets, Banks, and Economic Growth. American Economic Review, 88(3), pp. 537-58; Levine R., Loayza N., and Beck T. (2000a). Financial intermediation and growth: Causality and causes. Journal of Monetary Economics, 46, 31-77; Levine R., Loayza N., and Beck T. (2000b). Finance and the sources of growth. Journal of Financial Economics, 58, 261-300; Seetanah, B. (2008). 'Financial development and economic growth in an ARDL approach. Applied Economics Letter, 4(43), pp 43-50; Wachtel, P. (2003). How much do we really know about growth and finance? Federal.

${ }^{3}$ Levine, R., Zervos, S., (1996)., op cit.; Levine, R., \& Zervos, S. (1998). Stock markets, banks and economic growth. American Economic Review, 88, pp. 537-558.

${ }^{4}$ Levine and Zervos (1998)., op cit.

${ }^{5}$ Capital flow and Development of African Economies, United Nations Economic Commission for Africa Paper ECA/TFED/013/07 p 3

${ }^{6}$ Singh Ajit, should Africa Promote stock market capitalization? Journal of international development, vol.11(MayJune), pp.343

${ }^{7}$ Mwenda, K. M. (2000). Securities Regulation and emerging Market: Legal and Institutional Issues for Southern and Eastern Africa. Vol 7, No. 1. March.

${ }^{8}$ Allen, D. S. and Ndikumana, L. (2000)., Financial Intermediation and Economic Growth in Southern Africa. Journal of African Economies. Vol. 9(2): pp. 132-160; Asiedu, E. (2002)., On the Determinant of Foreign Direct Investment to Developing Countries: is Africa different? World Development, Vol. 30(1): pp. 107-119; Lamont, O and Polk, C. (2002)., Does Diversification Destroy Value? Evidence from the Industry Shocks. Journal of Financial Economics, Vol. 63(1): pp. 51-77 and The United Nations Conference on Trade and Development (UNCTAD). (2006)., Economic Development in Africa: Rethinking the Role of Foreign Direct Investment. New York and Geneva: The United Nations Conference on Trade and Development. 
supporting infrastructures that could aid their viability. ${ }^{9}$ Additionally, the volatility in the macroeconomics of a country may trigger a worrying volatility in the equity value of the locally listed firms. This problem may be compounded by market inefficiency that characterizes many capital markets in the developing countries. ${ }^{10}$ Conversely, these trends are gradually changing in Africa, as capital market development in Africa is gradually increasing with the improvement in performance being noticeable. Equally, the situation is also being appreciated by the increase in number, of the stock markets in Africa and their improving viability that can be attributed to the recent financial sector reforms undertaken by a number of African countries over the past decades ${ }^{11}$. Moreover, the reforms are evidently still on-going across the continent especially as will be considered in the course of this article in the case of the CEMAC zone. Altogether, with respect to these reforms initiatives, the African capital markets are fast becoming one of the top performers in the global capital markets trend. ${ }^{12}$

Explicitly, even though the CEMAC sub-region is currently hosting two stock exchanges, that is, the Douala Stock Exchange (DSX) and the Central African Stock Exchange (BVMAC), there is a pending agreement for their subsequent merger into a single CEMAC stock exchange by June $30,2019 .{ }^{13}$ In this regard, it is noted that the DSX found in Cameroon ${ }^{14}$ was created in April 2003, but effectively started trading in 2006; offering firms the opportunity to raise capital directly from domestic investors, with three companies ${ }^{15}$ so far listed as of January 2010; while the BVMAC with no listed company yet, is still to commence effective operation. This is in sharp contrast with other African nationals and regional stock exchange which in the same period from the date they started, that is, 10 years after, have listed more than 10 companies. ${ }^{16}$ Altogether, it should be recalled that the success of a stock market in terms of the number of companies listed may depend on several factors which may range from; the economic and political stability of the economy of the region or country, the financial and monetary sector, and most importantly, the legal framework of the market. In this light, these factors will be highly incorporated while considering the determinants and promotions of capital market development in general, and whether the legal framework of the CEMAC zone is appropriate in attracting more investors to list on their stock markets.

Altogether, another prime factor is the corporate governance on the issuance of shares and bonds under the OHADA Uniform $\mathrm{Act}^{17}$. In fact, the Uniform Act has certain conditions that constrain public limited companies to issue shares in the various stock exchanges. Equally, the legal framework of accounting and auditing under the OHADA needs to be reformed according to the International Financial Reporting Standard (IFRS) ${ }^{18}$ as the level of information provided by the OHADA accounting chart is considerably lower than that expected by international investors and lenders. Last but not least, another legal regime needs to be instituted for small and medium size

${ }^{9}$ International Monetary Fund (IMF). (2007)., Finance for African Companies: African Stock Markets Join Global Boom. Available at: http://www.imf.org/external/pubs/ft/survey/so/2007/CAR1012A.htm [accessed on 2009/04/06]

${ }^{10}$ Rangan, N. (1989)., The Takeover Mechanism as an Efficiency Enforcer: The Case of Bank Holding Companies. Journal of Managerial Finance. Vol. 15(4): pp. 18-22; Rangan, N. 1989. The Takeover Mechanism as an Efficiency Enforcer: The Case of Bank Holding Companies. Journal of Managerial Finance. Vol. 15(4): pp. 18-22; Lamont, O. (1997)., Cash Flow and Investment: Evidence from Internal Capital Markets. Journal of Finance, Vol. 52(1): pp. 83109; Fauver, L, Houston, J and Naranj, A. (2003)., Capital Market Development, International Integration, Legal Systems, and the Value of Corporate Diversification: A Cross-Country Analysis. The Journal of Financial and Quantitative Analysis, Vol. 38(1): pp. 135 -157; Jeffus, (2004)., op cit.; Vladimir, Tomislav \& Irena, (2013)., op cit.

${ }_{11}$ Ntim, C. G. (2012)., Why African Stock Markets Should Formally Harmonise and Integrate their Operations. African Review of Economics and Finance, Vol. 4(1): pp. 53-72.

12 African Securities Exchanges Association (ASEA). (2013)., Comparative Highlights (Graphs). Available at: http://www.africansea.org/ASEA/CStatistics.aspx [accessed 2013/10/16].

${ }^{13}$ Following a decision of the CEMAC Heads of State to unify the Stock Exchange of Central Africa (BVMAC) in Libreville, Gabon, and Douala Stock Exchange (DSX) in Douala, Cameroon, modalities for its operation have been set up. With the discussions to that effect having taken place during the 4th meeting of the Pilot Committee of the Economic and Financial Reform Programme of CEMAC in Douala January 29, 2018.

${ }^{14}$ Created by Law No 99/015 of the $22^{\text {nd }}$ December 1999

${ }^{15}$ Water Bottling Company SEMC; an Agro-Forestry Company SAFACAM, and an Agro-Industrial Company SOCAPALM. See www. Dsx.com

${ }^{16}$ The West African Stock Exchange (BVRM) of ECOWAS

${ }^{17}$ Organization for the Harmonization of Business Laws in Africa (OHADA), Uniform Act on Commercial Companies and Economic Interest Groups

${ }^{18}$ International Financial Reporting Standards 
enterprises in both markets. In this regard, it should be noted that a large portion of the economies in the CEMAC zone is still in the informal sector and, thus, raising long term capital from the money market seems impossible. Also, the legal conditions of these markets are too high and stringent for this category of economic operators. Thus, on its own, a developed capital market encourages domestic savings, thereby providing investable capital needed to fund further expansion of existing production capacity and ultimately enhancing economic growth. ${ }^{19}$ As a result, the development of capital markets in Africa especially in the CEMAC zone would serve as an important mechanism for generating expansion capital for local industries (including foreign investors), while accomplishing the portfolio diversification agenda of MNCs concomitantly. Therefore, given these compelling potential benefits of the development of viable capital markets, it becomes puzzling as to why the CEMAC countries are not initiating more capital markets and/or developing further the already established ones. The problem that now arises and is of prime importance is how best can the CEMAC countries enhance the development of a viable capital market framework that can enhance the inflow of FDI and, thus, the economic development of the sub-region. In this light, the article will consider the conceptual appraisal of capital market development, the legal framework of capital markets development in the CEMAC zone and then conclude with some viable recommendations.

\section{Conceptual Appraisal Of Capital Market Development:-}

Evidently, determining capital market development requires not only an understanding of its main determinants but also a clear definition of what 'capital market development' means and how progress toward it can be measured. In this regard, capital market development is defined as the process of improving the quantity, quality, and efficiency of stock market services. ${ }^{20}$ Therefore, capital market development is a multi-dimensional ideal, difficult, complex and long-term process. Moreover, the concept of capital market development should be strongly linked to the real sector and develop in proportion to economic activities. Also, it can be considered as the performance of stock market which is based on the increase or reduction in stock prices or returns. ${ }^{21}$ In this regard, a stock exchange is considered as a formal and regulated capital market where securities, that is, equity and debt, are issued (primary market) and traded (secondary market). Nevertheless, these markets can operate with securities which can either be equity securities, be it by means of an initial issuance or Initial Public Offering or by subsequent purchases and sales in the secondary market. Indeed, these markets facilitate the production of information, its dissemination and compensation amongst traders.

Therefore, to facilitate this interaction, the stock exchange provides a market place where new shares are issued in companies seeking a listing and where those shares can be traded between investors. ${ }^{22}$ In this light, stock exchanges are responsible for setting criteria which a company must meet to obtain a listing and comply with, in order to retain its listing. Thus, stock exchanges can better mobilize domestic and international capital because: (i) they offer a simple mechanism for the transfer of funds, which encourages investors to participate in the market, with this simplicity enabling individuals to finance long-term investments, even though most of them would have liked to commit their funds for only a short period of time; (ii) they permit companies to access a large number of investors scattered the world over, that is, when share prices are quoted publicly, the overseas' investors can gauge the level of domestic and international confidence in a particular company and the economy as a whole; (iii) they can appraise the financial conditions and future prospects of a company in need of funds, that is, the price of its securities and the magnitude of its price movements are clear indicators of the risk - return relationship involved; and (iv) they offer guidance to management through the cost of capital, that is, the market determined cost of capital assists in determining the level of investment appropriate for a company. ${ }^{23}$

Moreover, stock markets are well known for playing a very significant role in boosting economic growth through enhancing effective mobilization of savings for investment as well as facilitating capital inflows. They are important

\footnotetext{
${ }^{19}$ Kumar, (1984)., op cit; Enisan \& Olufisayo, (2009)., op cit; Vladimir, Tomislav \& Irena, (2013)., op cit.

${ }^{20}$ Samathan, B, Dasgupta, P and Pradhan, R.P. (2013). Finance Development and Economic Growth in BRICS: A panel data analysis. Journal of Quantitative Economics 11, Vol 1 (3), pp. 308-322.

${ }^{21}$ El-Wassal, K. A. (2013). "The Development of Stock Markets; In search of a theory.', International Journal of Economics and Financial issues, Vol 3 (3), 2013, pp. 606-624

${ }^{22}$ Noia, C. D., The stock exchange industry: network effects, implicit mergers and corporate governance, p. 21

23 Abayo, A.G. (1993). Corporate Disclosure Requirements and the Stock Exchange. The Tanzania Stock Exchange and Capital Market Initiative, Volume II.
} 
in mitigating investors' risks and in the transformation of maturities in the saving-investment nexus. ${ }^{24}$ They are also important in terms of enhancing productivity by improving the efficiency of financial intermediaries, raising the marginal productivity of capital as well as increasing the savings rate. ${ }^{25}$ In this regard, it has been argued that wellfunctioning stock markets enhance the efficiency of the corporate sector through ensuring an effective monitoring of management and exerting corporate controls. ${ }^{26}$ In fact, in the course of the past three decades, a good number of African countries have experienced some improvements in the development of their stock markets. Thus, during the period from 1980 to 1999, the number of actively trading stock markets in Africa rose steadily from 8 to $17 .{ }^{27}$ More so, in 2009, Africa had a total of 29 functioning stock markets across 23 countries $^{28}$ as against 17 in 1999 . Equally, a regional stock market ${ }^{29}$ was also established in 1998 by the French-speaking West African countries to serve equity markets in Benin, Burkina Faso, Cote d'Ivoire, Guinea-Bissau, Mali, Niger, Senegal and Togo. Altogether, even though the situation is still quite volatile, returns from the emerging African stock markets have been encouraging.

Conversely, in spite of the good performance of African stock markets, the bone of contention from empirical evidences still shows that the nexus between stock markets development and economic growth remained unresolved. In this regard, Corbett and Jenkinson found that 'the contribution of stock markets to corporate investment financing was negative in the UK but slightly positive in the United States during the 1970s and 1980s' ${ }^{30}$ Equally, in two other separate studies, Akyuz ${ }^{31}$ and Singh ${ }^{32}$ both found that unfavourable economic shocks from the interaction between stock markets and foreign exchange markets resulted in macroeconomic instability which in turns adversely affects economic growth. In fact, in view of the mixed empirical evidences on the link between stock market development and economic growth, this article will proceed to examine the existing literature about the conditions inhibiting the development of capital markets in sub-Saharan Africa (SSA) in general and the CEMAC zone in particular. However, except for countries like South Africa, Ghana, Nigeria, Kenya, and Zimbabwe, most capital markets in SSA are still in their formative stages. Thus, widening the scope of capital markets in most of these countries has gone hand in hand with the liberalization of the financial sector. Indeed, for countries in the CEMAC sub region, for example, the development of stock exchange is quite a recent issue. In this regard, the review of the academic literature and experiences of other SSA countries will throw more light and yield useful lessons for the CEMAC zone with similar economic situations. The following section considers the determinants of capital market development, while the next will dwell on the promotional appraisals of capital market development.

\section{The Determinants of Capital Market Development:-}

As elaborated above, many researchers have tried to find out the macroeconomic determinants of capital market development in developed and emerging countries. In this regard, ${ }^{33}$ since macroeconomic factors are important in stock market development, Calderon and Rossell have proposed a model that includes macroeconomic and institutional variables that might influence stock market capitalization. In the same token, Garcia and Liu show that

${ }^{24}$ Nissanke, M., Aryeetey, E., Hettige, H., \& Steel, W. F. (1995). Financial Integration and Development in SubSaharan Africa, Washington D.C. World Bank. Mimeo.

${ }^{25}$ Montiel, P. J. (1996). Financial Policies and Economic Growth: Theory, Evidence and Country-Specific Experience from Sub-Saharan Africa, Journal of African Economies, Centre for the study of African Economies (CSAE), 5(3), pp.76-79

${ }^{26}$ Stiglitz, J.E. (1985). Credit Markets and the Control of Capital, Journal of Money, Credit and Banking, 17(2), pp.133-152. http://dx.doi.org/10.2307/1992329

${ }^{27}$ Ndikumana, L. (2001)., Financial Markets and Economic Development in Africa. Working Paper Series, No 17, Political Economy Research Institute, University of Massachusetts, Amherst.

${ }^{28}$ Algeria, Botswana, Cote d'Ivoire, Cameroon, Egypt, Ghana, Kenya, Libya, Malawi, Mauritius, Morocco, Uganda, Mozambique, Namibia, Nigeria, Rwanda, South Africa, Sudan, Swaziland, Tanzania, Tunisia, Zambia \& Zimbabwe

${ }^{29}$ Bourse Regional des Valeurs Mobiliéres (BVRM) based in Abidjan, Cote d'Ivoire

${ }^{30}$ Corbett, J., \& Jenkinson, T. (1994)., The Financing of Industry, 1970-1989: An International Comparison. Discussion Paper No. 948, London: Centre for Economic Policy Research.

31 Akyuz, Y. (1993)., Financial Liberalization: The Key Issues in Finance and Real Economy, edited by Yilmaz Akyuz and Gunther Held. Santiago: United Nations University.

32 Singh, A. (1997)., Stock Markets, Financial Liberalization and Economic Development. Economic Journal, 107(442), pp.771-782. http://dx.doi.org/10.1111/j.1468-0297.1997.tb00042.x

${ }^{33}$ Calderon-Rossell, R. J. (1991). The Determinants of Stock Market Growth. In S. Ghon Rhee \& Rosita P.Chang (Eds.), Pacific Basin Capital Markets Research Proceeding of the Second Annual Pacific Basin Finance Conference, Vol. II, Bangkok, Thailand, 4-6 June, (Amsterdam: North Holland). 
macroeconomic factors such as real income, savings rate, financial intermediary development, and stock market liquidity are important determinants of stock market development. ${ }^{34}$ Equally, Pagano shows that regulatory and institutional factors may influence the efficient functioning of stock markets. ${ }^{35}$ For example, mandatory disclosure of reliable information about the firms may enhance the participation of investors, and regulations that instill investors' confidence in brokers should encourage investment and trading in the stock market. In the same frame of thought, La Porta et al. find that institutional variables such as rule of law, anti-director rights, and one share one vote are important predictors of stock market development. ${ }^{36}$ They also argue that the origin of a country's legal system affects the level of financial development and thus conclude that a 'common law basis' is more conducive to the development of capital markets than a 'civil law basis'; because the flexibility of the common law legal system allows for the protection of small investors. ${ }^{37}$ Moreover, they find that countries with a lower quality legal regime and poorer law enforcement, exhibit smaller and narrower capital markets and that the listed companies on their stock markets are characterized by more concentrated ownership. Equally, La Porta et al. ${ }^{38}$, Perotti and Van Oijen ${ }^{39}$, Galindo and Micco $^{40}$ and Djankov et al. $^{41}$ argue that strengthening property rights, credit protection and investor protection through company laws and commercial codes, as well as disclosure of companies' activities and proper accounting rules and practices are key determinants of the development of corporate securities markets. In this regard, the most important question is, what then determines capital market development? From the literature, it is found and suggested that some factors such as: sound macroeconomic environment, well developed banking sector, transparent and accountable institutions, and shareholder protection, are considered as the prime preconditions for the effective development and functioning of capital markets in general as will be appreciated in the CEMAC zone.

\section{Macroeconomic environment stability:-}

As a matter of fact, a stable macroeconomic environment is crucial for the development of the capital market. In this regard, macroeconomic volatility worsens the problem of informational asymmetries and becomes a source of vulnerability to any financial system. Thus, low and predictable rates of inflation are more likely to contribute to capital market development and economic growth. Conversely, both the domestic and foreign investors will be unwilling to invest in the stock market where there are expectations of high inflation. Apparently, Garcia and Liu, find that sound macroeconomic environments and sufficiently high-income levels (GDP per capita, domestic savings, and domestic investments), are important determinants of stock market development in emerging markets. ${ }^{42}$ In this regard, this situation can be appreciated in case of CEMAC zone with its macroeconomic potentials.

\section{Adequacy of banking sector development:-}

The development of the banking sector is very significant and crucial for stock market development in Africa in general and the CEMAC zone in particular. At the early stages of its establishment, the stock market is usually a complement rather than a substitute for the banking sector. Thus, developing the financial intermediary sector can promote the development of the capital market. In this light, many East Asian countries are successful examples. With the support services of the banking system contributing significantly to the development of the stock market.

${ }^{34}$ Garcia, V. and Liu, L. (1999), "Macroeconomic determinants of stock market development", Journal of Applied Economics, Vol. 2, pp. 29-59.

35 Pagano, M. (1993), "Financial Markets and Growth: An Overview”, European Economic Review, Vol. 37, pp. 613-622

${ }^{36}$ La Porta, R. F. Lopez-de-Silanes, Shleifer, A., Vishny, R.W. (1996), Legal Determinants of External Finance. The Journal of Finance, 52(2), pp. 1131-1150

${ }^{37}$ La Porta, R., F. Lopez-de-Silanes, Shleifer, A., Vishny, R.W. (1999), Investor Protection: Origins, Consequences, and Reform. Financial Sector Discussion Paper No. 1, Washington, D.C: World Bank.; La Porta, R., Lopez-deSilanes, Shleifer, Vishny, R.W. (1998), Law and Finance. Journal of Political Economy, 106, pp. 1113-55.

${ }^{38}$ La Porta, R., Lopez-de-Silanes, F., Shleifer, A., Vishny, R. (2002), Investor Protection and Corporate Valuation. The Journal of Finance, 57(3), pp. 1147-70.; La Porta, R., F. Lopez-de-Silanes, Shleifer, A., Vishny, R.W. (2000), Investor Protection and Corporate Governance. Journal of Financial Economics, 58(1-2), pp. 3-27.

39 Perotti, C.E., Oijen, P.V. (2001), Privatization, Political Risk and Stock Market Development in Emerging Economies. Journal of International Money and Finance, 20(1), pp. 43-69.

${ }^{40}$ Galindo, A., Micco, A. (2004), Creditor Protection and Financial Markets: Empirical Evidence and Implications for Latin America. Federal Reserve Bank of Atlanta Economic Review, second quarter.

${ }^{41}$ Djankov, S., La Porta, R., Lopez de Silanes, F. and A. Shleifer, A. (2005), The Law and Economics of SelfDealing. NBER Working Paper No. 11883.

${ }^{42}$ Garcia and Liu, L. (1999)., op cit. 
Consequently, liquid inter-bank markets, largely supported by an efficient banking system, are important for the development of the capital market. Conversely, a weak-banking system can constrain the development of the capital market. On the empirical front, Demirguc-Kunt and Levine, find that 'most stock market indicators are highly correlated with the development of the banking sector' ${ }^{43}$ Thus, countries with well-developed stock markets tend to have well developed financial intermediaries. In this same token, Yartey finds that a one percentage increase in the banking sector development, increases stock market development in Africa by 0.59 percentage, thereby, contributing to macroeconomic stability, economic development and the quality of legal and political institutions. ${ }^{44}$

Viability of institutional quality:-

The institutional quality is important for capital market development because efficient and accountable institutions tend to broaden appeal and confidence in equity investment. Equity investment, thus, becomes gradually more attractive as political risk is resolved over time. The development of good quality institutions can affect the attractiveness of equity investment, thus, leading to capital market development. In this light, Yartey finds that good quality institutions such as law and order, democratic accountability, and bureaucratic quality are important determinants of stock market development in Africa because they reduce political risk and enhance the viability of external finance. ${ }^{45}$ In the same token, Bekaert on his part provides evidence that higher levels of political risk are related to higher degrees of market segmentation and consequently low level of stock market development. ${ }^{46}$ Moreover, Erb et al. show that expected returns are related to the magnitude of political risk. ${ }^{47}$ They find that in both developing and developed countries, the lower the level of political risk, the lower is the required returns. Therefore, the evidence in the literature suggests that political risk is a priced factor for which investors are rewarded and that it strongly affects the local cost of equity, which may have important implications for capital market development.

\section{Magnitude of shareholder protection:-}

Another key determinant of stock market development is the level of shareholder protection in publicly traded companies, as stipulated in securities or company laws. ${ }^{48}$ Indeed, stock market development is more likely in countries with strong shareholder protection because investors do not fear expropriation as much. In addition, ownership in such markets can be relatively dispersed, which provides liquidity to the market. In this regard, $L a$ Porta et al. provide evidence on the importance of the protection of minority rights by using indicators of the quality of shareholders' protection as written in laws. ${ }^{49}$ They demonstrate that the quality of shareholders' protection is correlated with the capitalization and liquidity of stock markets in 49 countries around the world. In this regard, they find that countries with lower quality of legal rules and law enforcement have smaller and narrower capital markets and that the listed firms on their stock markets are characterized by more concentrated ownership. ${ }^{50}$ Equally, Demirguc-Kunt and Maksimovic show that firms in countries with high ratings for the effectiveness of their legal systems are able to grow faster by relying more on external finance. ${ }^{51}$

Ardently, in addition to the above major determinants, various researchers have adopted different variables to estimate capital market development. Notable amongst these studies are the work of Allen and Ndikumama, who used - the credit provided to the private sector; the volume of credit provided by banks, and the liquid liabilities of

${ }^{43}$ Demirguc-Kunt, A. and Levine, R. (1996b). "Stock Market Development and Financial Intermediaries: Stylized Facts," The World Bank Economic Review 10 (2), pp. 291-321

${ }_{44}^{44}$ Yartey, C. A. (2008). Determinants of stock market development in emerging economies: Is South Africa different? IMF working Paper-WP/08/32 Washington, International Monetary Fund

${ }^{45}$ Ibid

${ }^{46}$ Bekaert, G. and Harvey, C. R. (1995). Time-Varying World Market Integration. Journal of Finance, Vol. 50(2): pp. $403-444$.

${ }^{47}$ Erb B. C.,Harvey, C. R. and Viskanta, T. E. (1996): "Expected Returns and Volatility in 135 Countries," Journal of Portfolio Management, spring, pp. 32-48

${ }^{48}$ Shleifer, A. and Vishny, R. (1986): "Large Shareholders and Corporate Control" Journal of Political Economy, Vol. pp. 94 461-88

${ }^{49}$ La Porta, R., F. Lopez-de-Silanes, A. Shleifer and R. Vishny (1998)., op cit., pp. 1113-1155

${ }^{50}$ La Porta, R., F. Lopez-de-Silanes, A. Shleifer and R. Vishny (1997), Legal Determinants of External Finance, Journal of Finance 52: pp. 1131-1150.

${ }^{51}$ Demirgüç-Kunt, A. and Maksimovic, V. (1998). Law, Finance, and Firm Growth, Journal of Finance 53, pp. 2107-2137 
the financial system in their study of capital market development in Southern Africa. ${ }^{52}$ According to these authors, the greater the credit provided to the private non-financial sector as a percentage of the overall credit, the greater the possibility of capital efficiency and the greater the potential for economic growth. They argued that these proxies of financial development are good measures of the efficiency with which the financial system allocates resources to the economic sectors, with more emphasis on the private sector, as a way of stimulating growth. Also, King and Levine construct four empirical indicators of capital market development that are designed to measure the level of services provided by financial intermediaries for achieving economic growth. ${ }^{53}$ More so, a few other studies adopt stock market indicators in assessing the financial development in advanced economies. For instance, Davis constructs four variables as indicators of financial development as stock market capitalisation, stock market turnover, listed companies and bank credit. ${ }^{54}$ This author is of the opinion that financial development is best measured through the twin aisles of the financial market components, that is, the stock market and the credit market. Equally, Oura adopts the ratio of external (bank) finance to total firm finance as a measure of financial development. ${ }^{55}$ The author also shares the same line of thoughts with previously mentioned researchers that performances of the agents of intermediation (banks) are the main determinants of the depth of capital market. ${ }^{56}$ Therefore, it is noted that together with the above considerations, the promotional measures are readily pivotal in enhancing the development and functioning of the capital market as will be considered below.

\section{The Promotion of Capital Market Development:-}

Apparently, as reiterated above, the African stock markets especially those in the CEMAC zone are still small, illiquid, with infrastructural bottlenecks and weak regulatory institutions. In fact, despite these problems, the stock markets in Africa have readily helped in the financing of the growth of large corporations, but however, there is little evidence of broader economic benefits. Thus, the question posed is, how do you make the stock market more beneficial for African countries in general and the CEMAC countries in particular? A great number of propositions have been suggested to enhance the development of these stock markets. These range from the need to increase automation, demutualization of exchanges, regional integration of exchanges, promotion of institutional investors, regulatory and supervisory improvements, involvement of foreigner investors, and educational programmes ${ }^{57}$ Most of these propositions involve substantial benefits as well as cost outlays. This section, therefore, looks at the future of African stock markets by examining the policy options that can lead to their promotion and development.

\section{Emergence of automation:-}

Ardently, it is noted that automation can help reduce the costs and inefficiencies in African stock markets, thereby, increasing trading activity and liquidity. In this regard, automation involves the implementation of computerized and electronic systems for trading, clearing and settlement purposes. Thus, in automated exchanges, the placement and matching of buy and sell orders are computerized and not constrained by location. Automation, therefore, helps in speeding up operations and activities of exchanges, thereby, reducing cost associated with the manual systems. In addition, automation makes it easier to extend trading days and hours due to less cumbersome procedures. Equally, automated trading also eliminates the need for trade intermediation, since investors can log onto systems to monitor the markets and also trade on markets, thus, bypassing the use of brokers. In fact, the automation of the trading system usually either precedes or is preceded by the adoption of a central depository system (CDS). Under the CDS system, there is total elimination of risks such as the loss, mutilation and theft of certificates associated with holding and trading of paper-based securities of investors. CDS systems also reduce errors and delays associated with paperbase. However, automation is an expensive venture and has huge budgetary implications for African governments. This might explain why most African stock markets have found it difficult to fully automate their systems. ${ }^{58}$

\footnotetext{
${ }_{53}^{52}$ Allen and Ndikumana (2000)., op cit.

${ }^{53}$ King, R.G., and Levine, R. (1993c)., Finance and Growth: Schumpeter Might Be Right. Quarterly Journal of Economics. Vol. 108(3): pp. 717-738.

${ }^{54}$ Davis, E.P. (2004)., Financial Development, Institutional Investors and Economic Performance. In Goodhart, C. A. E. (Ed.), Financial Development and Economic Growth: Explaining the Links. London: Palgrave-Macmillan.

${ }^{55}$ Oura H. (2008)., Financial Development and Growth in India: A Growing Tiger in a Cage? IMF Working Paper No: 08/79.

${ }^{56}$ King \& Levine (1993c)., op cit; Davis, (2004)., op cit; Naceur, Ghazouani \& Omran, (2007)., op cit.

57 Yartey, C. and Adjasi, C. (2007). Stock Market Development in Sub-Saharan Africa: Critical Issues and Challenges, IMF Working Paper, August

${ }^{58}$ So far, the only African stock exchanges with automated and Central Depositary Systems are the Algiers Stock Exchange, Bourse Régionale des Valeurs Mobilières (BRVM), the Cairo and Alexandria Stock Exchange (CASE),
} 
Conversely, with the proliferation of electronic communication networks (ECNs) and alternative trading systems (ATS), the cost of automation is gradually reducing. In this light, other African stock exchanges can adopt the Namibian model whereby the Namibian Stock Exchange (NSX) uses the trading system of the Johannesburg Stock Exchange (JSE) of South Africa. The markets could also adopt the CDS systems in similar manners. ${ }^{59}$ Admittedly, the operational procedures of such an approach are likely to be difficult in the absence of currency convertibility issues and harmonized financial systems. Thus, automation is particularly important if African stock exchanges aim at integration. Without automation the much-touted benefits of regional stock market integration is likely to be lost.

\section{Galvanising demutualization:-}

It can be considered as a change in the legal status, structure and governance of an exchange from a non-profit, protected interest one to a profit oriented. ${ }^{60}$ Indeed, the process of demutualization involves a change in ownership structure and a change in legal and organization form. With regards to the ownership structure, members' seats are monetized and values assigned per seat. Members then either keep or sell shares. Ownership restrictions are placed on individuals and groups to prevent potential takeovers by other exchanges. The legal and organizational change normally entails the exchange becoming a typical profit-making company with limited liabilities and abiding by company laws. Demutualization started gaining popularity in the 1990s, due to a number of factors. These include competition among exchanges, need for increased capital, need for good corporate governance in exchanges and the urge to open up ownership of exchanges to public investors. ${ }^{61}$ Between 1999 and 2003, the number of demutualized and public exchanges in the world increased from 10 to $25 .{ }^{62}$ Demutualization is expected to solve mutual structure problems by opening up trading rights, admitting new trading partners, and broadening ownership such that the public can invest in exchanges. The absence of these in mutual exchanges tends to breed poor governance structures. In a mutualized exchange, traders and brokers enjoy monopoly power through exclusive rights and access to trading systems, resulting in a protection of vested interests for traders. In a demutualized exchange, there is a vote per share and once incentives for equity stakes to non-members exists, there is separation of powers. Decision making is on ownership structure not trades intermediation. Thus, demutualization induces better corporate governance systems. In addition, undue governmental influence in mutual exchanges in Africa is likely to be absent in demutualized exchanges since appointment of government officials become unnecessary due to the fact that a demutualized exchange is a private company. Demutualization also increases access to services of the exchange and removes excessive investment costs for fund holders. For instance, brokers usually package non-trade related fees into institutional traditional commissions often known as "soft commissions" or "bundled commissions" and pass on to clients. With demutualization, fund holders can directly access such information without the use of brokers. Finally, it is also argued that demutualization instills efficiency and better structures in exchanges and results in commercial gains for exchanges. ${ }^{63}$ Altogether, a major problem with demutualization is that of conflict of interest and regulatory oversight. Exchanges tend to shy away from taking enforcement actions against their own customers who are a source of income. There is a potential commercialization of services; data and trade information that traditionally was offered freely is now sold; listing standards and oversight can be compromised by the exchange concerned.

Apparently, to solve these problems, self-listing arrangements can be implemented. For instance, in Singapore, the Singapore Stock Exchange (SGX), the Singapore Stock Exchange Security Trading (SGX-ST) and the monetary authority have a regulatory arrangement whereby SGX-ST is the frontline regulator for firms listed on the SGX and the SGX itself is subject to the same rules applicable to other firms, the Monetary Authority is the overall overseer. Indeed, for mutual African stock exchanges, potential conflict of interest could pose huge problems, since their current regulatory structures are still undergoing restructuring to meet international standards. Therefore, in many African countries as seen in the case of the CEMAC zone, the establishment of formal stock exchanges usually

Stock Exchange Mauritius, Namibia Stock Exchange (NSX), Nigeria Stock Exchange, Johannesburg Securities Exchange (JSE), Tunis Stock Exchange and the Lusaka Stock Exchange.

${ }^{59}$ Yartey and Adjasi (2007)., op cit.

${ }^{60}$ The process can be defined as a change in legal status of the exchange from a mutual association with one vote per member (and possibly consensus-based decision making) into a company limited by shares with one vote per share (Akhtar, S. (2002). "Demutualization of Asian Stock Exchanges-Critical Issues and Challenges," in Shamshad Akhtar ed. Demutualization of Stock Exchanges, Solutions and Case Studies, Manila: Asian Development Bank).

${ }^{61}$ Pirrong, C. (2000). "A Theory of Financial Exchange Organization," Journal of Law and Economics 43 pp.437-71

${ }^{62}$ IOSCO (2005). "Exchange Demutualization in Emerging Markets," Emerging Markets Committee of the International Organization of Securities Commission IOSCO, April

${ }^{63}$ Ryden, B. (1995). "The Reform of the Stockholm Stock Exchange," Stockholm Stock Exchange, November. 
precede the creation of formal independent securities regulators. However, it could also be argued that perhaps being a private venture, demutualized exchanges could speed up the formation of strong regulatory systems in Africa. Altogether, it noted that the policy of demutualization is not of immediate concern to most African exchanges. The reason for this is that most African exchanges have barely existed for three decades and are grappling with teething issues of poor infrastructure and illiquidity. More importantly, demutualization would be more relevant in the medium to long term when the teething issues have been properly managed. Indeed, demutualization should be considered as the next step after Africans have consolidated more gains in improving their liquidity problems and strengthening cooperation. However, Yartey and Adjasi point out that for now other African markets can study the JSE to learn from their current experiences as a demutualized exchange but equally admitted that the JSE case poses a challenge for advocacy for a regional exchange for SADC. ${ }^{64}$ This is because a regional exchange in the SADC in the near future is expected to be demutualized given the current stance of the JSE.

\section{Enhancement of regional integration:-}

Another proposed solution to the problems faced by African stock markets especially those in the CEMAC zone, is the issue of integration of the stock exchanges. Indeed, the merging of stock exchanges (the extreme form of integration) results in volumes multiplying with potentially the same overhead costs. ${ }^{65}$ Thus, merging African stock markets into a single regional exchange immediately is no doubt an ambitious and daunting task, given the associated institutional and financial cost complexities. Therefore, proponents of this proposition argue that a wellintegrated regional stock exchange in Africa will be a powerful source and driver of capital flows to Africa. Such an exchange will also, if well structured, solve the current problems of illiquidity, small size, and fragmentation. In this regard, the issue of integration is highly expected to solve the fragmentation problems of the CEMAC stock exchanges, with the advent of the agreement of a possible merger of the stock exchanges in the zone. This will promote cost efficiency and improve liquidity and price discovery. With investors able to execute orders without routing through brokers, since there is only one payment of listing fees in an integrated exchange. Integrated markets harness a pool of economic and human capital; with the economic and human capital skills of various markets brought to play in a single market. The market, thus, benefits from a rich and diverse pool of skills. Integration fosters synergies in risk management, since risk is spread thin across market segments, which prior to integration, were national exchanges. Integration reduces complexities, since all trading, operations, clearing and settlement systems are harmonized. It also improves surveillance and risk management, by enabling access to information in all market segments. Therefore, one problem that hinders successful stock markets integration is nationalistic politics.

Conversely, most African governments tend to view stock exchanges as national assets with pride just like national airlines. ${ }^{66}$ As a result, they are uncomfortable with transformations which lead to a reduction in the national touch. In addition, smaller economies tend to perceive the bigger economies as being domineering and fear that their exchanges will be overshadowed by the bigger exchanges with integration. These economies also fear that capital may be diverted away from them to the bigger economies with integration. For instance, Okeahalam reports that Botswana officials were uncomfortable with South Africa's virtual African exchange proposal due to the fear of capital flight towards JSE ${ }^{67}$ More so, there are important preconditions for successful regional approaches such as the legal harmonization (trading laws and accounting standards) and a liberalized trade regime. Explicitly, effective integration requires that there are harmonized legislation, rules, listings, trading days, settlement, and reporting standards. This implies that for African stock markets to become integrated, the various national exchanges must adopt and/or harmonize their existing rules and systems. This can be potentially a long and arduous task for these exchanges. Therefore, even if the trading rules and listing requirements are harmonized, there is the issue of accounting and reporting standards. These standards tend to be based on national systems which in turn also based on the colonial history of the countries. For instance, the BRVM comprises of countries which adopted common standards following their common colonial past. Altogether, integration cannot be successful in the absence of

64 Yartey, C. and Adjasi, C. (2007)., op cit.

${ }^{65}$ Claessens, S., Klingebiel, D. and Schmukler, S. (2002). "Explaining the Migration of Stocks from Exchanges in Emerging Economies to International Centers," World Bank Working Paper No. 2816, Washington.

${ }^{66}$ Moss, T. (2003). "Adventure Capitalism: Globalization and the Political Economy of Stock Markets in Africa," London: Palgrave Macmillan

${ }^{67}$ Okeahalam, C. (2001). "Strategic Alliances and Mergers of Financial Exchanges: The Case of the SADC," presented at the fourth Annual Conference of the Centre for the Study of African Economies, Oxford University, March 19-31 
automated systems. In this line of thought, the urgency of integration readily requires investors and traders to be able to $\log$ on into trade from other stations and this requires the assistance of automated and viable systems. ${ }^{68}$

Equally, currency convertibility is very important in an integrated exchange. An integrated exchange with a multiplicity of inconvertible currencies only compounds the administrative costs which integration itself seeks to remove. Here the advantages of having existing monetary unions, like the WAEMU in the case of the BRVM preclude such problems, as equally seen in the case of CEMAC. Moreover, this is the main reason why the SADC region is progressing quickly towards a regional stock exchange due to the convertibility of most of the regions' currencies. Africa has many currencies, few of which are convertible within the continent. Indeed, currency convertibility depends more on the trade density between two countries and cannot be forced. This, therefore, places hurdles on the way of regional exchange integration efforts. Thus, the experience of BRVM can teach us a number of lessons on stock market integration in Africa. ${ }^{69}$ With the first being that it takes a long period of time to build a regionally integrated exchange, and the second being that a regionally integrated exchange established does not mean that it will be used effectively or that it will integrate the markets. In this regard, the sustainability and success of any regional project must be very carefully assessed before the project is undertaken. Private sector participation, as opposed to just regulators, central banks and other public institutions normally has the best incentive to determine whether the expenditure on a particular integration scheme for market infrastructure is worthwhile.

\section{Promotion of institutional investors:-}

The involvement of institutional investors in African exchanges must be pursued vigorously. Institutional investors often are at the forefront in promoting efficient market practices and financial innovation. They typically favour greater transparency and market integrity in both primary and secondary markets, seek lower transaction cost, and encourage efficient trading and settlement facilities. ${ }^{70}$ Indeed, the pension Funds, insurance houses and other institutional investors can, therefore, act as a countervailing force to commercial and investment banks as well as other market intermediaries, forcing them to be more competitive and efficient. In fact, African exchanges stand to gain enormously from increasing the involvement of institutional investors on their stock exchanges.

\section{Strengthening regulation and supervision:-}

Regulation and supervision of the financial system play a great role in determining both its stability and the extent of services provided. In this regard, regulation and supervision are typically aimed at protecting the investors from the potentially opportunistic behaviour of insiders. Investor protection helps solve agency problems and information asymmetry arising from inside information. ${ }^{71}$ This helps in making optimal decisions, increasing access to external finance and resulting in productive investment and eventually higher firm growth. ${ }^{72}$ There is the need for a wellstructured and clear rule of law, within an efficient judicial system, which allows for contract repudiation and expropriation risk in this regard. Moreover, regular disclosure, transparency and enforcement form an integral part of regulation and supervision. Thus, important disclosure requirements include relevant information with regards to transactions, accounting and the identity of ultimate beneficial owners. ${ }^{73}$ They must be nonetheless simple and supportive of the legal and accounting framework. ${ }^{74}$ Similarly, enforcement procedures need not be long, cumbersome and expensive. Since enforcement essentially requires compliance and the ability to prosecute; thus, the presence of a securities regulator is very important in this regard to ensure enforcement. Such enforcement can also be complimented by effective private laws on contracts and dispute resolutions. ${ }^{75}$ The presence of strong

${ }^{68}$ Yartey and Adjasi (2007)., op cit.

69 Asea, P. (2003). "Promoting Regional Financial Market Integration,"Presented at the African Capital Markets Development Workshop, Johannesburg, South Africa, October 27.

${ }^{70}$ Yartey and Adjasi (2007)., op cit.

71 Regulation is the set of rules imposed by the authorities on the actions of participants in financial markets. Supervision is the manner in which the authorities verify and enforce compliance with the requirements of the regulatory framework.

${ }^{72}$ La Porta, R., Lopez-de-Silanes, F. and Shleifer, A. (2003). "What Works in Securities Laws?" NBER Working Paper No. 9882, Boston: National Bureau of Economic Research

73 Yartey and Adjasi (2007)., op cit.

74 Friedman, B. and Claire Grose, C. (2006). "Promoting Access to Primary Equity Markets: A Legal and Regulatory Approach," Policy Research Working Paper No. 3892 Washington: The World Bank

${ }^{75}$ Lopez-de-Silanes, F. (2004). "A Survey of Securities Laws and Enforcement," Policy Research Working Paper No. 3405, Washington: The World Bank 
corporate governance mechanisms also help to boost investor confidence in regulatory issues. Moreover, strict ethical and conduct of business rules could be developed for members of African stock exchanges. Indeed, these rules must follow international best practices but at the same time should reflect the needs and local structures. In this same token, the emerging African markets should also implement rules that are "necessary" rather than what would be "nice". ${ }^{76}$ Equally, in SSA especially in the CEMAC zone, there are laws and rules for regulation and supervision. However, the real challenge is the shortage of experienced supervisors and the absence of a strong tradition favoring compliance with the rules and discouraging regulatory forbearance. ${ }^{77}$

Altogether, it can be synopsized that this section of the article has vividly discussed the underpinning conceptual appraisal of capital market development. Thus, it has been shown that from previous studies, there is a great link between the determinants and promotional measures with respect to capital market development, but however, this is far from definitive. Moreover, it is noted that the existing literature tend to focus overwhelmingly on the analysis of developed countries ${ }^{78}$ but failed to decouple the relative contribution of banking and stock market development on economic growth in a single framework. In this light, this article therefore aims to enhance, depart from and contribute to the existing literature in various ways. In the first instance, it is aimed to focus on the CEMAC zone and simultaneously examine the legal frameworks and determinants of stock market development on economic growth in a unified framework. Therefore, in corroboration with the great efforts made to appraise and envisage the trend and prospects of capital market development in Africa in general and the CEMAC zone in particular; some hindrances to capital market development still persist, especially with regards to the challenges that hinge on the legal and institutional inefficiencies, clearly elaborated above. Thus, the next section will evaluate the legal frameworks and prospects of the development of a viable capital market in the CEMAC zone.

\section{Legal Appraisal Of Capital Markets Development In The CEMAC Zone:-}

Apparently, it should be reiterated that huge portions of appraisal on the subject matter in this part will focus on the works of scholars who are legal personnel of international financial institutions. Their approach as per the various regional groupings of Africa has inspired us to look at the possible reasons why the Central Africa Stock Exchanges are not viable enough. Thus, Mwenda argues that imperfect market conditions can affect the capital structure decisions of many corporate investors in emerging markets, and further states that these constraints can affect the contribution of the legal framework for public distribution of securities to the development of a competitive stock exchange. ${ }^{79}$ Indeed, on the one hand, it is noted that he indirectly suggests an integration and/or creation of a viable regional stock exchange. However, reviewing the situation of the CEMAC regional stock exchange, it is noticed that there is a problem to effectively kick-off. Equally, on the other hand, he also proposes the need of a central financial service regulator, which according to him could improve the performance of the entire financial service sector. In the same token, other authors like Kehl, ${ }^{80}$ follow the similar position like Mwende, but move further to think that, any higher returns for African countries is to identify the area in the markets that are performing well and improve it.

Moreover, another survey of the existing literature shows that various factors affect the development of stock exchanges in developing countries like countries in the CEMAC zone. Some authors categorize some of the factors as institutional (regulations, information, disclosure, transparency rules and trading cost), traditional (market capitalization, amount of capital raised through stock offering, number of listed companies and turnover), and finally, asset pricing (efficiency with which market prices risk and the degree of integration into world market) ${ }^{81}$ Furthermore, others emphasize the central role played by governments, in facilitating the development of stock exchanges in developing countries by first laying solid legal and institutional foundations, followed by supervising

\footnotetext{
${ }^{76}$ Friedman and Grose, (2006)., op cit.

77 Vittas, D. (1998). “Institutional Investors and Securities Markets: Which Comes First?” World Bank Working paper 2032, Washington: The World Bank.

78 Atje and Jovanovic (1993). op cit., Levine and Zervos (1998)., op cit.

79 The Securities Regulation and emerging markets: Legal and Institutional Issues for Southern and Eastern Africa. And in Legal Aspects of Financial Services Regulation and the concept of a unified regulator. See Mwenda, K. K. (2000). Security Regulation and Emerging Mark\$\$ \$et: Legal and Institutional Issues for Southern and Eastern Africa, March, p. 3

${ }^{80}$ Kehl, J.R. (2007)., Emerging Markets in Africa, Research Paper.

81 Demirguc-Kunt, A. and Levin, R. (1993)., "Stock Market Development and Financial Intermediary Growth," World Bank Policy Research Working Paper, Washington: World Bank, 56
} 
the market to ensure its efficient, fair and stable operation. ${ }^{82}$ Altogether, in this article, these views form the baseline in further evaluating the economic and institutional constraints of the development of capital markets in the CEMAC zone. Indeed, as stated earlier, before the advent of the decision of the CEMAC Heads of States passing a resolution on the merger of the Central African capital markets, the sub-region has hosted two stock exchanges, that is, DSX and BVMAC, with each stock exchange having its separate regulatory body and different rules and regulations applicable. Therefore, in its struggle for maintenance alongside the CEMAC regional exchange comprising of six countries, the DSX scored valuable points in December 2009, at the close of the first bond issue made by the International Finance Corporation (IFC) in CEMAC. In fact, with an amount of 20 billion FCFA (30.5 million USD), the DSX operation has demonstrated a high ability to mobilize larger savings than the BVMAC. In the same token, with this successful operation with the World Bank's subsidiary in the first bond issue, the government of Cameroon (GoC) launched a second bond issue of 200 billion for 2012-2019. ${ }^{83}$ Altogether, comparing with the BVMAC, which is still to list a company, the DSX can at least boost of three listed companies.

Apparently, some of the objectives for creating the DSX, were to facilitate the privatization programme, granting of credit in Cameroon and for the BVMAC to take fully, the investment potentials of the region. Since the region has witnessed an increase in the exploitation of mining fields and the discovery of huge oil reserves in Chad and Equatorial Guinea. However, the pertinent question that one can ask is; why has there been no company listed in the BVMAC, despite the huge presence of many multinational and local companies in the region. And in Cameroon, why despite the privatization of more than sixteen (16) huge state-owned companies, none has been listed on the DSX. ${ }^{84}$ Conversely, the Banking sector in the region is still strivings in issuing short term loans despite the presence of these stock exchanges. Thus, this plainly explains why companies still depend on the banks for loans instead of going to the capital markets in Douala and Libreville. Furthermore, the regulatory framework of the Central African stock exchanges is not attractive enough to investors; judging from the fact that a good number of companies in the region are small and medium in size and cannot raise the required capital to be listed in the stock exchanges. It has been asserted that the regulatory bodies ${ }^{85}$ of the stock markets need to be more pro-active in their approach in educating the public on the various aspects of the markets. This is to avoid instances whereby, non-actors not registered in the markets, may foul the public and investors of possible investment opportunities in the markets which do not exist. ${ }^{86}$ Equally, this is to boost investors' confidence which is a crucial ingredient for capital markets.

Moreover, the OHADA corporate governance framework applicable to the region does not help matters much. It is enshrined in its Uniform Acts on Commercial Companies and Economic Interest Groups that only companies operating within the CEMAC zone with capital of 100 million FCFA and above, are allowed to list their shares on the stock exchanges. In the same light, it also states that, companies with less than three (3) shareholders will be automatically unlisted in the stock exchanges. Equally, the above piece of legislation also allows for the creation of single shareholder companies. However, it should be noted that in the region most businesses are small and medium sized enterprises (SMEs), mostly in the form of sole proprietorships and partnerships. Thus, without a market regime for these SMEs, the number of listed companies in the various stock exchanges will be low or almost non-existent. This statement can only be true because the bigger companies in the region are MNCs. Therefore, a harmonized fiscal legislation on both markets could be a stepping stone to enhance the better performance of the stock exchanges. Therefore, for the case of the DSX, to attract more underwriters and issuer, the GoC has initiated a number of tax incentives, for instance, there are tax reduction for a company wishing to do business at the DSX; which will go for a period of three years. In this regard, issuers may, if necessary benefit from a rate of up to $10 \%$ or a substantial reduction compared to the ordinary rate of $35 \%$. This provision applies to unlisted companies making a public offering and who agree to exchange shares or debts to the stock exchange.

\footnotetext{
${ }^{82}$ Perdy, R. (1992)., "Institutional Reform in Emerging Securities Market”, World Bank Policy Research Working, Washington, World Bank.

${ }^{83} \mathrm{http} / / \mathrm{www}$. afribiz.info/content/Cameroon-laws and regulation consulted on 22-02-2015

${ }^{84}$ Nzomo, J. T. and Nzongang, J. (2007)., The process of privatisation of the public and para-public enterprises in Cameroon: An assessment. Journal for sustainable development in Africa, vol. 9, No.4

${ }^{85}$ Conseil du Marché Financier (CMF) for the DSX and Commission de Surveillance du Marché Financier de l'Afrique Centrale (COSUMAF) for the BVMAF

${ }^{86}$ A communique from the Financial Market Commission signed on the 27 January 2012, warning the public and investors in Cameroon of a website publication (www.cgfbourse of the CGF Bourses Society) of which CGF was talking of possible investments in Treasury Bonds worth 40 Billion FCFA over a period 2012-2019 with a 5.95\% interest rate. Cameroon Tribune, Tuesday January 31, 2012
} 


\section{The Structure of the Capital Markets in the CEMAC Zone:-}

Explicitly, the stock exchange markets are considered as primary capital markets for the initial issuance of securities or secondary capital markets for the trading of securities previously issued. In this regard, a stock exchange has to ensure that the market place for securities which it operates works efficiently and transparently as possible. In the same token, a stock exchange regulates the direct access of the market place through membership admission and subsequent rules. ${ }^{87}$ Thus, the revenue of the stock exchange is mainly derived from the following sources: (i) trading fees (membership and trading fees); (ii) listing fees (initial and yearly listing fees); (iii) information and price dissemination fees; (iv) settlement fees, and finally, from the development and sales of proprietary software. Apparently, there are usually two kinds of customers in a stock exchange, which are the direct and indirect customers. On the one hand, the direct customers of stock exchanges are those on the services list of the stock exchange and the intermediaries who are admitted to trade as well as information vendors; while on the other hand, the indirect customers are those who send orders to the intermediaries to execute on the stock exchange. Therefore, single customers (physical or legal entities), institutional investors and all other financial intermediaries are not allowed to trade directly as well. ${ }^{88}$ In this regard, a very important aspect of a stock exchange is its regulation; which refers to the establishment of rules, the process of rule-making and the legislative acts and statutory instruments issued by the national and supra-national competent authorities.

\section{Prudential norms in the securities market:-}

Generally, financial market regulation is organized around two poles: the regulation of the market and the regulation of the actors. Apparently, this is very clear in France where before the reforms of 21 January 2010, the prudential regulation of enterprises was done by the Financial Market Authority (AMF), the Ministry in-charge of Economy ${ }^{89}$, the Banking Commission ${ }^{90}$ and in certain measures by the 'Committee of Credit Establishments and Investment Enterprises' (CECEI) ${ }^{91}$. Thus, there was a clear distinction between the Financial Market Regulations and the Prudential Regulations (regulations of actors). This distinction was even clearer after the reforms of 21 January 2010, since the Financial Market Regulations were conferred to the AMF, while the regulation of actors was vested in the 'Agence de Regulation Publique' (ARP). However, this is not the case in Great Britain where the banking, financial and insurance activities are all controlled by one authority - the Financial Service Authority (FSA). In this light, the system of prudential regulation within the OHADA zone is unique and original because it has borrowed from both the French and British systems, thus, having a combination of the two approaches ${ }^{92}$.

\section{Increase of prudential rules applicable to banks and financial actors:-}

The prudential rules are a body of management norms aimed at ensuring financial stability in a given economic sector; far from making any separation between the prudential rules of actors and that of the market: ${ }^{93}$ and equally far from concentrating the two types of regulations into the hands of a unique financial regulator. ${ }^{94}$ However, the combination of the two models within the OHADA zone leaves a model which is a cohabitation of the two. Thus,

${ }^{87}$ Ibid

${ }^{88}$ Ibid

${ }^{89}$ The Minister controls service providers who do not fall within the competence of the AMF, he lays down the amount of the required capital taking into consideration services which will be provided by the investment service provider in question (Article L.611-3,10, of the Monetary and Financial Code), the organization of common services, the management norms to be respected in views of guaranteeing liquidity, solvency and the equilibrium of the financial sector, the publication of information destined for competent authorities, the rules applicable to accounting organizations, the mechanism of control and security in the domain of computer as well as the internal control procedure (Article L.611-3,2 of the Monetary and Financial Code).

${ }^{90}$ The Banking commission was in-charge of ensuring the respect of prudential by the investment service providers. These rules were established by the Ministry of Economy.

${ }^{91}$ The CECEI was an organ competent to the access of professionals providing financial services in a situation where exclusive competence was not given to the AMF.

${ }^{92}$ Keuffi, D.E. (2010)., 'La regulation de marches financières dans l'espece OHADA, These du Doctoral, Faculte de Droit, de Science Politique et de Gestion, Universite de Strasbourg, p. 143.

${ }^{93}$ This is the American dualist model which is adopted by many countries amongst whom are France, Finland, Luxemburg, Spain, Italy and Australia. For a justification of why France belongs to this model. see J.P. VALETTE, GUALINO (editor), 2005, p. 11

${ }^{94}$ This is the model of Great Britain which is adopted by countries like Germany, Belgium, New Zealand, Hungary and Japan. 
while the transversal rules of the OHADA Uniform Acts apply to actors of the financial Market and those of the monetary market, these two sectors remain submissive to particular prudential rules. It should be noted that the amount is not limited to the issuing companies but equally applies to the financial intermediaries who must equally take the form of a public limited company (PLC). Indeed, where the capital goes below the authorized minimum, the financial intermediary concerned shall lose his authorization and, in this case, shall adopt a company form that is incompatible with those of the stock exchange in order to exercise its activities. In fact, the respect of the stock exchange rules is ensured by the company accountants. Therefore, PLCs making a public call for capital must have two principals and two assistant auditors. ${ }^{95}$ They have as roles to certify that the financial statements of the company are regular, sincere and give a true picture of the operations of the company, ${ }^{96}$ and are, thus, logically required to control the amount of capital since it is an element of the assets of the company. In the same token, the rules of the Uniform Act on Accounting also aimed to reduce to a minimum, the risk that can be incurred by the different economic agents. ${ }^{97}$ Although banks, financial establishments and insurance companies are not concerned with the OHADA Accounting system, they must respect the principle posed by its Article $3^{98}$ as well as the national laws governing the area. Moreover, the banks and stock markets within the CEMAC zone, respect specific rules applicable to them. These prudential rules usually have different sources depending on whether they are applicable to the banks or the stock exchanges and are, thus, in reality susceptible to apply concurrently to professionals.

\section{Partition of competence in the banking and stock exchange sectors:-}

Apparently, in the banking sector, the establishment and control of prudential norms is done by separate organs while in the stock exchange sector, the establishment and control of the prudential norms is done by one independent regulating authority.

Prudential Competence in the Banking Sector: Within the CEMAC zone, it is the COBAC which establishes prudential norms applicable to credit establishments. In this regard, COBAC defines the prudential norms and elaborates the accounting procedure applicable to credit establishments operating within CEMAC ${ }^{99}$. The prudential norms established by COBAC are the quantitative norms of solvency and liquidity as well as the quantitative norms of risk management. In fact, originally fixed at 5 percent, the solvency norms defined by COBAC have been readjusted to 8 percent, with effect from 1 January 2002, in order to match with the international standards prescribed by the Bâle Committee ${ }^{100}$. Readily, this ratio of risk cover was modified entirely to meet with international regulations. Equally, from the quantitative view point, COBAC has placed emphasis on internal control which is aimed at giving a sense of responsibility to the management organ of credit establishments in the domain of mastering and preventing risk. Also, the respect of prudential rules laid down by COBAC is ensured by BEAC on behalf of COBAC which nevertheless is still competent to inflict sanctions on violators. ${ }^{101}$

Prudential Competence in the Stock Exchange Sector: The prudential rules applicable to issuers, financial intermediaries and market structures within the CEMAC zone are laid down by COSUMAF, and by CMF in the Cameroonian financial market. Thus, the regulating authorities of the Central African financial markets occupy a central place as far as the prudential regulation of the market is concerned. In fact, contrary to the banking regulators who have only a limited competence, the financial market regulators are charged with the elaboration, control and

\footnotetext{
${ }^{95}$ See Article 702 UACCEIG.

${ }^{96}$ See Article 710 UACCEIG.

97 This Uniform Act is applicable to businesses governed by commercial Law (whether they are corporate entities or natural persons), public and semi-public companies, cooperatives and more generally any entity manufacturing and producing marketable or non-marketable goods and services, if that entity habitually exercises an economic activity (whether for financial gain or otherwise and whether the activity concerned is its main or merely accessory to its main activity). However, an express exception excludes from this list, entities that are subject to public accounting rules applicable in member states concerned

${ }_{98}$ Article 3 provides that, companies must comply with the obligation of regularity, accuracy and transparency.

${ }^{99}$ See Article 3 of the annex of the convention of 16 October 1990 on the creation of the banking commission of Central Africa, COBAC eventually establishes (with the opinions of national authorities) the accounting plan and procedure applicable to these establishments as well as the liquidity ratio, the cover and the division of risk.

100 This ratio of 8\% called the Cook's ratio fixed at the Accord of Bâle, was replaced in 2006/2007 by a new ratio

${ }^{101}$ Kalieu, Y. (2002)., le contrôle bancaire dans la zone de l'Union Economique et Monuètaire de l'Afriaue Central, Penant, no 841, October - December. pp. 445-472.
} 
sanction of prudential rules applicable to financial intermediaries ${ }^{102}$ and to collective organs of security placement ${ }^{103}$. The general competence of these authorities runs from the establishment of prudential rules right to subsequent investigators which are always awaited.

\section{Overlap of the prudential competence in both sectors:-}

The competence in the domain of prudential rules within the OHADA zone interweave the professions and the activities, ${ }^{104}$ since one activity can be common to several professions just like one profession can cover many activities. This is, thus, seen in case of the banking profession within the OHADA, which can cover credit activities as well as investment activities. Therefore, banks within this zone are capable of providing investment services, such as placement, purchase, management stock and sale of securities or all financial products ${ }^{105}$. Indeed, Article 266 of the General rules of COSUMAF, expressly authorizes banks to create collective investment schemes (OPCVM) ${ }^{106}$. These organs are required under the control of financial regulators to respect their prudential rules. Therefore, the banking regulators exercise control over the OPCVMs in their role of prudential supervision. In this context, it is evident that the banking establishments supply investment services, while in certain measures, their management of the OPCVM confuses the nature and importance of the different prudential rules because they are issued by different authorities. However, the solution to this problem is found in the establishment of a platform of corporation between the different prudential regulators. While this measure for the creation of a Uniform Act covering this sector is still awaited, there is an urgent need for the creation of a communication exchange means between the different authorities in charge of prudential regulations. This can take the form of exchange of information, and the initiation of institutional cooperation between the different organs charged with prudential regulations. Indeed, having briefly analyzed the financial sector in the CEMAC zone and considered the partition of competence in the banking and stock exchanges sectors; it is, therefore, appropriate to consider the primary and secondary legislation the various capital markets in the CEMAC zone, in order to evaluate the determinants and constraints of their developments.

\section{The Legal Framework of the Capital Markets in the CEMAC Zone:-}

As provided above, the CEMAC zone is composed of six states in the Central African sub region. This region is composed of about 35 million inhabitants in population, of which Cameroon alone has more than 55\% of the population. Indeed, as reiterated above, before the advent of the decision of the CEMAC Heads of State to merge the BVMAC in Libreville and the DSX in Douala, with headquarter in Douala - Cameroon. The sub-region has hosted two stock exchanges as a result of the fight of leadership between Cameroon and Gabon, with regards to the nation which was to host the Regional Stock Exchange ${ }^{107}$. In this regard, a vivid perusal of these two stock exchanges will be provided, to situate the urgency of the merger. Conversely, it will be realized that while the DSX is governed by national laws complemented by the OHADA laws, the BVMAC is governed by CEMAC regulations which are also complemented by the OHADA laws and the national laws of the Member States. In this light, in order to have a better understanding of the urgent need of a merger, we will vividly consider the legal and institutional frameworks of the two stock exchanges.

\section{Legal framework of the Douala stock exchange:-}

As outlined above, consideration will be made on the primary and secondary legislation of the Douala Stock Exchange (DSX), to bring out the salient issues and situate the contour of this article. The primary legislation establishing the DSX is Law No. 99/015 of 22 December 1999, creating and organizing the financial market of Cameroon. ${ }^{108}$ The 1999 law is supported by other national laws regulating the Douala Stock Exchange, such as Decision No. 02/002 of 3 December 2002, relating to the General Rules of the Financial Market Commission. While the secondary legislation are those apart from the national laws, that is, other laws that are being applied in the domain of financial market in Cameroon, since Cameroon is not only a member of the international treaties and

\footnotetext{
${ }^{102}$ See Article 84 of the General Rules of COSUMAF.

${ }^{103}$ See Article 270 of the General Rules of COSUMAF.

${ }^{104}$ Keuffi, D. E., op cit. p.148.

${ }^{105}$ See Article 8(4) of the annex to the convention of 17 January 1992 on the harmonization and regulation of banking within Central African States.

${ }^{106}$ Operation de placement collectif des valeurs mobilier

${ }^{107}$ Molinot., La CEMAC, victim de la bataille nationaliste entre le Cameroun et le Gabon, marches tropicaux, p.737

${ }^{108}$ This legal text has 41 Articles, divided into six chapters. Chapter 1 deals with the general provisions, chapter 11 with the provision of investment services, chapter 111 with public call for capital, chapter 1V with the Financial Market Commission, chapter V with Stock Exchange and chapter V1 crowns the text with Offences and Sanctions.
} 
regional laws, but is a country which was colonized by Britain and France, which up to date still applies the laws of its colonial masters in areas which have not yet had national legislation or when the national legislation have lacunae. Indeed, the fact that laws of colonial masters can still be apply in Cameroon can be supported by section 11 of the Southern Cameroons High Court Law of 1955, which provides that, the laws which would be applicable in former Southern Cameroons will be the common law, the doctrine of equity and statutes of general application which were applicable in England before the first day of January 1900. Apart from the laws of colonial masters, Cameroon has ratified the CEMAC and OHADA treaties permitting their laws to be applicable in Cameroon and even to take precedence over national laws by virtue of Section 43 of the 2006 Constitution of the Republic of Cameroon as amended. In fact, both the OHADA and CEMAC have laid down rules applicable to stock exchanges; although the OHADA has permitted the specific rules of stock exchanges of the member states to remain applicable. However, what poses a problem is the fact that Cameroon is a member of the CEMAC financial market, which means that CEMAC laws in this domain are supposed to be applicable in Cameroon but conversely, Cameroon has its own sets of rules which govern its financial market. Therefore, there is a likelihood of conflict between these two laws. While some people are advocating for a merger of the two stock exchanges, Alexander Gandou, the chairman of the supervisory board of the BVMAC had earlier shown his support for the separate markets. In an interview published by les Afrique, he stated that 'there should be a harmonization of regulations, so that the same rules should apply to both stock markets; and so that if there is any problem in the market, the regulations speak in one voice. ${ }^{109}$

Douala Stock Exchange (DSX): Apparently, the DSX is a public limited company (PLC) with a Board of Directors and capital of 1.8 billion FCFA, of which $63.7 \%$ of the shares are held by private commercial banks, Credit Foncier of Cameroon and the Dutch bank FMO, $23 \%$ by public interest, and $13.3 \%$ by private insurance companies. The DSX is charged with the organization of the trade of transferable securities and other investment products registered in any of its department. To this effect, it takes upon itself the exclusive rights to regulate: access to the market; admission to quotation; organization of transactions and the market; suspension of negotiations; recording and publication of negotiation; and conclusion of transaction. It has the powers to monitor the legality of the operations carried out by the stockbrokers (Investment Service Providers - PSIs) acting as negotiators-compensators or by any persons acting on their behalf. ${ }^{110}$ The DSX informs the Financial Markets Commission of any irregularities, disrespect of market regulations, collusion between two or more participants or any other abnormality likely to negatively affect the integrity of the market. The DSX has the powers to immediately sanction any action that is contrary to the interest of the market ${ }^{111}$. This power shall be a protective measure aimed at immediately stopping any action that is prejudicial to the market. ${ }^{112}$

Financial Market Commission (CMF): It is the regulatory body of the DSX. It was created alongside Law No. $99 / 015$ of the 22 December 1999 which created the DSX. ${ }^{113}$ Its mission is to protect portfolio investors in the bourse as well as other investments in the public offering of shares. It is to inform the investor, control the intermediaries of the market (the PSI - as they are known on the DSX) and supervise the good functioning of the companies in the bourse. It is headed by an appointee by the President of the Republic. All its eight legible members include: two representatives of the Ministry of Finance, two qualified personalities proposed by the Minister of Justice, one representative of the association of the investment companies in the bourse, one representative of credit institutions and lastly two qualified personalities selected as per their expertise in securities market. They are all appointed by the President of the Republic. The President of the Commission has the final say as per the voting decisions of the commission. For the CMF to function smoothly, it has come out with rules and regulations of the DSX with regards to the way the DSX should function, rules of professional practice, management rules and accounting obligations. It also has the powers to provide rules of good conduct, control, inspection and rules relating to compensation or investment protection. The CMF defines the legal regime of the public offering of shares. In its mission to control the good functioning of the securities market, the CMF can; instruct the opening of an enquiry during a negotiation between the public offerer and a PSI, informs its immediate hierarchy to modify texts on the public offering, the activities of the PSI and finally the companies dealing in the markets. ${ }^{114}$ The CMF receives all disputes from participants in the market and also has the competence to take decisions on general and individual issues. Moreover,

\footnotetext{
${ }^{109}$ See businessincameroon.com. 20 January 2010

${ }^{110}$ See Article 7 of the rules and regulations of the Douala Stock Exchange of 03-12-2002

${ }^{111}$ Ibid., Article 7

${ }^{112}$ Ibid., Article 8

113 Ibid., Article 14

${ }^{114}$ Ibid., Article 22
} 
The CMF is financed partly by dues and commissions from its activities and also from state grants. By this, the CMF must present an annual balance sheet of its finances. The functions of the CMF have clearly shown that the success or failure of the Cameroonian financial market lies to a very large extend in the hands of the CMF. If the CMF fails to discharge the duties vested upon it, that is, by putting in place the rules and regulations of the DSX, the market will never be credible. In this regard, it should be noted that the credibility of the rules and regulations of the DSX will to a very large extend, depend on the caliber of persons who will be appointed in the CMF.

General Rules and Regulations of the Douala Stock Exchange: These are determined rules relating to: the organization of the market; the negotiation of transferable securities; the acceptance, listing and delisting of stocks, shares and transferable securities; special operations; the conclusion of transactions; and the setting of the prices for services. Thus, on a general basis, the Central Depository and the settlement and clearance banks in relation to the activities of custody, circulation of stocks and cash payments shall be subjected to the same approval conditions and procedures in these rules and regulations.

Other Actors of the Cameroonian Financial Market: The financial market of Cameroon has two (2) other actors with DSX, in performing the different functions in ensuring the proper functioning of the market. These other actors are; (i) the Investment Service Providers (PSIs), which are persons who transmit to the stock exchange orders to buy or sell shares, which are issued by their clients in order that the demand and supply of the shares and securities can be met. Moreover, the PSIs are investment enterprises and credit establishments ${ }^{115}$ who are authorized to supply investment services. ${ }^{116}$ In this light, the PSIs must be Public Limited Companies (PLCs) having more than one shareholder. ${ }^{117}$ Thus, PLCs having a single shareholder ${ }^{118}$ cannot perform the services of PSI. Also, the PSIs shall receive, transmit and execute orders on behalf of their clients. They can equally negotiate shares for their personal accounts, manage the security portfolio on behalf of the clients and perform the function of placing. ${ }^{119}$ With placing being the situation where the PSI contracts can make an effort in passing the securities of an issuer to customers, and is being paid for this; but if the securities are not bought it is the issuer who loses. ${ }^{120}$ Indeed, for the PSI to perform one of the functions mentioned in the above paragraph, he/she must fulfill the following conditions: be registered in Cameroon; have an authorized minimum capital determined by the $\mathrm{CMF}^{121}$; identify its shareholders and directors as well as their respective share amounts; present a profile of the directors for approval by the CMF; the company must equally have at least one approved accountant; be a form which is allowed to perform the services of an PSI; and present a plan of action for each service that it is going to engage in. ${ }^{122}$ Thus, having taken the initiative and engagement to perform the services outlined above, the PSIs are not allowed to exercise any professional activity other than those listed above. With the other actor being, (ii) The Market Enterprise which is a financial establishment which has been given an exclusive concession of the public service. Its partners are the PSIs. This means that only banking institutions or credit establishments which have been approved by the CMF can perform the services of the market enterprise. Thus, the market enterprise has as object, the follow-up of the activities of PSI, the management of the Stock Exchange Market and to manage suspensions of negotiations. ${ }^{123}$ The objective of the market enterprise should be included in its Articles of Association. In fact, the market enterprise principally regulate access into the market, admission of quotation, organization of transactions on the market, suspension of one or more securities, registration and publication of negotiations and the conservation of securities.

115 See Article 4 of the annex to the Convention of 12 January 1992, on the harmonization of the Banking Regulations in the Central African States which defines credit establishments as organs which effect habitually the operations of banks.

${ }^{116}$ See Article 6 of Law N ${ }^{\circ}$ 99/015 of 22 December 1999, creating and organizing the financial market of Cameroon. 117 See Article 62 of the 2002 Decision on the General Regulation of the Financial Market Commission.

118 See Article 385 (2) of the UACCEIG permits a PLC to be formed by a single a single person.

${ }_{119}$ See Article 5 of Law N ${ }^{\circ}$ 99/015 of 22 December 1999, creating and organizing the financial market of Cameroon

120 Kembo, T. G. (2003)., 'La responsibilite penal des acteurs du Financier dans la loi N ${ }^{\circ}$ 99/015 du 22 Decembre 1999 portant creation d'une marche financière au Cameroun, memoir de DEA, FSJP, Universite d Dschang, p.42

${ }^{121}$ According to Article 68 (a) of the 2002 Decision on the General Regulation of the Financial Market Commission; the amount will be 100 million FCFA for a PSI acting as a negotiator, compensator, conservator, asset manager etc and 150 million FCFA for a PSI who accumulates these activities.

${ }^{122}$ See Article 8 of Law N ${ }^{\circ}$ 99/015 of 22 December 1999, creating and organizing the financial market of Cameroon

${ }^{123}$ See Article 45 of the 2002 Decision on the General Regulation of the Financial Market Commission. 


\section{Legal framework of the CEMAC stock exchange (BVMAC):-}

Explicitly, just like the case of the DSX, before the advent of the merger resolution, two sets of legislations are applicable to the BVMAC. The primary legislation or text governing the CEMAC Stock Exchange is Regulation No. 06/03-CEMAC-UMAC of 11 November 2003, on the organization, function and supervision of the financial market of Central Africa ${ }^{124}$. In addition to this text, is the Additional Act No. 03/01-CEMAC of 8 December 2001, creating the supervisory commission of the Financial Market of Central Africa (COSUMAF), the Additional Act No. 100/00-CEMAC-C-CE-02 of 14 December 2000, fixing the headquarters of BVMAC, and Regulation No. 14/07-UEAC-175-CM-15 of 19 March 2007, instituting a specific tax regime applicable to quotation operations on the Stock Exchange of Central Africa. Apparently, while the secondary legislation applicable to the BVMAC includes the OHADA laws since the member states of CEMAC are also members of OHADA, with the scope of the Uniform Act covering the offerings. ${ }^{125}$

Supervisory Commission of the Financial Market of Central Africa (COSUMAF): It is the main regulatory, supervisory and control organ of BVMAC, which has a legal personality ${ }^{126}$ different from that of its members. It is composed of nine (9) members chosen by the ministerial committee of UMAC after taking into consideration their recognized expertise in terms of accounting, finance and legal knowledge. The members of COSUMAF are appointed in the following order: Six (6) members representing the Member States and proposed by the States; a representative of the Bank of Central African States (BEAC), proposed by its Governor; a representative of the Executive Secretary of the executive secretariat of CEMAC under the proposal of the Executive Secretary; a representative of COBAC under the proposal of the Secretary General of COBAC. ${ }^{127}$ The conference of Head of States of CEMAC shall under the proposal of the Ministerial Committee of UMAC and under the presentation of the government of Congo, appoint the President of COSUMAF, whose term of office is five (5) years renewable. ${ }^{128}$ The Ministerial Committee of UMAC shall appoint the Secretary General of COSUMAF, after the opinion of the commission and under the presentation of the government of Central Africa Republic. His term of office is five (5) years renewable and can be revoked in the same manner as the members of COSUMAF. ${ }^{129}$ In fact, the attributes of COSUMAF are found in Articles 10-13 of Regulation No. 06/03-CEMAC-UMAC of 11 November 2003, relating to the organization, functioning and supervision of the Central African Financial Market. Indeed, from the provisions of Article 10, COSUMAF can legislate by way of regulations, instructions and opinion. In case of failure, its members shall be sanctioned. Furthermore, COSUMAF shall exercise control and supervision over operations concerning the public call for capital; institutions charged with the good execution of transactions on the regional financial market and notably the Regional Stock Exchange; over physical and moral persons authorized to participate at the regional financial market. ${ }^{130}$ Therefore, because of the heavy task vested on COSUMAF, its members have been given immunity from prosecution. However, this immunity will not cover fraudulent, negligent and malevolent omissions. ${ }^{131}$ In addition to the market regulators (regulatory bodies) discussed above, there are other actors of the Central African Stock Exchanges who must not be neglected in a document of this magnitude.

\footnotetext{
${ }^{124}$ This is divided into eight Titles. Title I deals with the definition and organization of the BVMAC; Title II deals with the control and supervisory authority of the Financial Market of Central Africa (COSUMAF); Title III deals with the market Enterprise of the BVMAC, Title IV covers the rules of security negotiation; Title V governs the execution conditions of stock operations; Tile VI deals with the compensation fund; Title VII covers illicit practicessanction and prohibitions and Title VII deals with final provisions. Indeed, prior to this regulation, the CEMAC legislation adopted additional Act No 11/00-CEMAC-C-CE-02 of the December 2002 fixing the headquarters of the CEMAC stock exchange at Libreville, Gabon, Additional No 03/01-CEMAC-CE-03of December 2001 creating the commission of supervision of the Financial Market of the Central Africa (COSUMAF) and Additional Act No 08/CEMAC-CE-04 of $23^{\text {rd }}$ January 2003 fixing the headquarters of COSUMAF at Libreville.

${ }^{125}$ See Article 81 et seq. Uniform Act Commercial Companies and Economic Interest Groups

${ }^{126}$ See Article 6 of Regulation $\mathrm{N}^{\mathrm{o}}$ 06/03-CEMAC-UMAC of 11 November 2003 relating to the organization, functioning and supervision of the Central African Financial Market

${ }^{127}$ Ibid., Article 14

${ }^{128}$ Ibid., Article 17

${ }^{129}$ Ibid., Article 18

${ }^{130}$ Ibid., Article 12

${ }^{131}$ Ibid., Article 13
} 
Other actors of the CEMAC financial market:-

In this regard, we have three (3) actors of the CEMAC Financial Market, (i) the Central African Stock Exchange, (ii) the Stock Company, Agents of exchange and approved representatives of stock companies and (iii) the Regional Securities Deposit Bank.

Central African Stock Exchange (BVMAC): It has the exclusive competence to organize, manage and animate the Regional Financial Market. Being a Public Limited Company (PLC) governed by the private law, it respects the provisions of the OHADA Uniform Act on Commercial Companies and Economic Interest Groups. It is equally bound to respect the rules of COSUMAF in the discharge of its duties. In fact, only PLC and Private Limited Companies (LTD) can be registered in the Trade and Personal Property Register (TPPR) of a CEMAC Member State. Also, an institution approved by COSUMAF can be a shareholder of BVMAC. ${ }^{132}$ This provision strictly limits the number of persons who can be shareholders of the BVMAC, since natural persons cannot be shareholders.

Stock Companies, Agents of Exchange and Representatives of Stock Companies: These are persons who are allowed to participate either on their own or as intermediaries on the stock market. Thus, to perform the functions of a stock company, the company must meet up with the following requirement: be in possession of a valid license; employ at least two agents of exchange; and hold at least one share in BVMAC. Indeed, these conditions are aimed to eliminate adventurers from the financial market. Also, the stock company is authorized to use the services of one or more approved representatives who would act in her name and account to transmit or collect orders of purchase or sale of securities or accomplish any formalities relating to these orders and/or to execute these orders. These agents or representatives can only act with the authorization of COSUMAF and are not allowed to perform any other function apart from those stated above. ${ }^{133}$

Regional Securities Deposit Bank (CRDV): Apparently, the community legislator did not give any definition to the CRDV but merely states its functions. From this, it can be understood that the CRDV is a company governed by private law and a bank where securities and charges over securities are conserved. In this light, it can take one of the forms listed in the introduction, as defined by Article 6 of the OHADA Uniform Act on Commercial Companies and Economic Interest Groups. It will in addition, to respecting the provisions of OHADA, respect the laws regulating the regional financial market. Altogether, the CRDV will perform the following functions: conserve the stock listed on the regional stock exchange; take account of stocks registered in the register of stock and its deposit effected by one of its adherents on his account or on the account of his client; be a third-party pledge of stocks which have been pledged; regulate and deliver stocks which have been quoted on the regional stock exchange. Moreover, it shall equally make a balance between stocks bought and those sold on the regional exchange.

Altogether, in summary, it can be reiterated that the success of the stock exchanges will to a large extent depend on the availability of information on the stock market operations and the solvency of the market actors. This information will guide investors and the public on the nature of the risk they intend to bear. Investor will only participate in the stock exchange if their protection is guaranteed. Thus, as provided above, there are two stock exchanges currently established in the CEMAC zone. However, it should be noted that their exercise and operation have serious incompatibilities at the regulatory, judicial and financial levels. Thus, the co-existence of the two stock exchanges has resulted in: the legal insecurity related to overlapping of the regulations of the management and supervisory organs of the two financial markets; the duplication of the operating and capital expenditure of the two financial markets; and lastly the activities of the two stock markets are limited with no evident that there is a potential market to ensure the viability of both, as underscored by both BEAC and IMF. Altogether, it has been appreciated that, the publication of price sensitive information is highly protective to investors because the information documents are usually being kept opened for verification by the public. Thus, the public and investors can always have some basic information concerning the company with which they intend to trade with on the stock exchanges. Also, the guarantee fund which is aimed at compensating persons who suffer some prejudice following the bankruptcy of the PSI, further strengthens the production. In addition to this, the use of civil and criminal sanctions against violators of financial market rules and regulations has deterred participants from violating these rules and has thus accord some protection to the investors.

\footnotetext{
${ }^{132}$ Ibid., Article 29

${ }^{133}$ Ibid., Article 39
} 


\section{Conclusion:-}

Apparently, this article has provided a periscopic review of the determinants of capital market development in general and how they relate to the problems in the CEMAC zone. Indeed, based on the analysis presented above, it is found that the financial sector reform has led to more players in the capital market; with the entry of more financial institutions in the financial sector setting in motion a competitive banking environment. In addition, the financial resource mobilization has also shown some improvement as evidenced by the increases in deposit growth. However, this deposit growth was not matched by increases in credit to the private sector. In fact, various reasons explain the above anomaly. Therefore, it should be noted that despite the various objectives in establishing the CEMAC Stock Exchange (BVMAC) and the Douala Stock Exchange (DSX), which are preempted on the premises on the provision of viable opportunities for investors to transform their stock holdings into liquidity form when it is needed. In fact, it has been realized that due to the infighting and conflict of interest between the member states within the CEMAC zone; the stock markets in the zone have not been buoyant enough to attract FDI into the zone with low return on investments. With the repercussion that the return on investments readily provides sufficient signals for investors to participate in raising long-term capital for expansion and growth, with the resulting effect in encouraging the inflow of FDI into the viable zone.

Moreover, in the same token, the article examined whether the main factors with respect to the development of the stock market in emerging market countries can also help in understanding the specific case of the CEMAC zone. In this regard, the analysis found four interesting results. Firstly, the income level, domestic investment, banking sector development, private capital flows, and the stock market liquidity are the important determinants of stock market development in emerging markets. Secondly, the relationships between the development of the banking sector and the stock market in emerging market countries is non-monotonic. This finding, therefore, suggests that at early stages of its development, the banking sector is a compliment to the stock market in financing investment. However, as they both develop, the banks and the stock markets begin to compete with each other as vehicles for financing investment. Thirdly, the institutional factors such as political risk, law and order, democratic accountability and bureaucratic quality are important determinants of stock market development in the CEMAC zone. This result thus suggests that the resolution of political risk can encourage investor confidence and propel the growth of the stock markets in the CEMAC zone, with this being appreciated at the advent of the merger resolution by the Heads of State of the CEMAC zone. Finally, the factors explaining the development of the stock market in emerging market countries are readily appreciable because they provide the spectrum to identify and analyse the determinants of capital markets development in the CEMAC zone.

Altogether, from the analysis of the primary and secondary legal and regulatory framework of the stock exchanges in the CEMAC zone, it is observed that the primary legislation of both stock markets by themselves, definitely draw their sources from the existing legal framework that have succeeded. Thus, it is realized that the supervising authorities have done much to get companies listed in the various stock exchanges. These measures by themselves are not enough because it is noticed that, the OHADA Uniform Act on Companies has its own weight to bear on the companies and economic interest groups that will be interested in getting listed in the stock exchanges. These stock markets have different compartments: those that deal with issuance of Treasury bond, which has done well so far in raising funds for some governments and another compartment dealing with the trading in shares and debts, which have performed poorly since the inception of both stock markets. The questions that, therefore, stand are, should both institutions be merged especially in the domain of Treasury bond compartment, and keep their individual shares and debts compartment or should there be a total merger of both institutions.

All in all, there is a strong recommendation for a total merger of both stock markets. This suggestion will be good for all investors whether found in Gabon, Cameroon or other CEMAC member states, to be governed by the same set of rules. Therefore, to succeed, the BVMAC and DSX need to strive for the harmonization of their rules and subsequently merge into one single capital market. In this regard, the Association of African Stock Exchanges has already taken major steps towards this direction even though much still need to be done. However, in the same token, kudos to the leaders of the CEMAC states for their marvelous initiative early 2010 at Bangui, to have brainstormed and recommended for the harmonization of the financial market regulations of the stock exchanges of CEMAC zone; which has subsequently bore more fruits following the decision of the CEMAC Heads of State in November 2017, resolving to merge the BVMAC and DSX, with headquarters in Douala. As reiterated above, the merger is paramount because both capital markets are serving the same purpose, with almost identical technical resources and procedures, thus, the need of a merger. This corroborates the studies on BVMAC and DSX merger carried out by a team of French consultants of the Roland Berger firm as part of its mission to the COSUMAF. 
Furthermore, to achieve these enormous initiatives, it is therefore highly recommended that priority should be given to the legal, institutional and technical modalities for the merger, as well as identified the risk factors that may delay the merging, notably the cost involved in bringing together the different components and redeploying workers. In this regard, it is recommended that a technical unit attached to the Pilot Committee of the Economic and Financial Reform Programme of CEMAC should be set up, the recruitment of an independent firm to propose measures for the implementation of the merger should be done, as well as the need to solicit development partners to help fund the merger process and finalisation. Indeed, it is believed that if all these are done, then foreign investors will be encouraged to invest on the merged stock exchange. In the same token, since the financial market acts as a catalyst to economic development, these initiatives will vibrantly improve the financial system and thus enhance appropriate financial regulation of the CEMAC zone. Therefore, it is incumbent on the regulatory authorities to, thus, integrate the quality measures in the process of the elaboration and adoption of rules in order to attract compliance on the part of the actors and enhance the efficiency in the application of the rules. Affirmatively, it can also be alluded that if all these viable recommendations are given the utmost considerations and implementation, then the resolved merger of the capital market in the CEMAC zone will be an important instrument in solving the financial needs of each State of the CEMAC zone, thus, attracting more and more FDI and ensuring proper coordination in the domain of financial information and profession ethics in the zone. 